\title{
Konstruksi makna proses kreatif pada kreator di biro iklan
}

\author{
Teddy Kurnia Wirakusumah
}

Universitas Padjadjaran, Bandung, Indonesia

\begin{abstract}
ABSTRAK
Artikel dengan judul konstruksi makna proses kreatif pada kreator di biro iklan bermaksud untuk memahami makna yang dikonstruksi oleh kreator iklan tentang proses kreatif yang mereka alami ketika membuat karya iklan. Pertanyaan penelitian yang diajukan adalah bagaimana kreator iklan mengkonstruksi proses kreatif yang mereka alami ketika bekerja membuat karya iklan menurut pandangan mereka sendiri. Metode penelitian yang digunakan adalah metode kualitatif dengan tradisi fenomenologi. Subjek penelitian yang dipilih adalah kreator iklan di Bandung dan Jakarta sebanyak 12 orang. Pengumpulan data dilakukan dengan metode wawancara mendalam. Sejumlah pertanyaan yang diajukan dibuat dalam bentuk daftar pertanyaan terbuka dan berlangsung dalam suasana informal. Hasil penelitian mengungkapkan bahwa tahapan yang lazim dilewati dalam pembuatan iklan di biro iklan adalah mengumpulkan informasi, menggunakan informasi, melakukan brainstorming, mengembangkan gagasan, melakukan review, eksekusi, artworking, presentasi, dan produksi. Dalam tahapan-tahapan pembuatan iklan yang dilalui oleh informan, ternyata proses kreatif yang berlangsung dalam diri informan tidak hanya terpusat pada salah satu tahap saja tapi tersebar pada semua tahapan dengan corak rangsangan yang khas. Kreator Iklan telah mengembangkan proses kreatif mereka berdasarkan berbagai jenis rangsang; yaitu proses kreatif berdasarkan rangsang rujukan data, proses kreatif berdasarkan rangsang pengalaman lama, proses kreatif berdasarkan rangsang pertukaran gagasan dan argumentasi, proses kreatif berdasarkan rangsang pengalaman baru, proses kreatif berdasarkan rangsang tidak terduga, proses kreatif berdasarkan rangsang kendala teknis, dan proses kreatif berdasarkan rangsang kompromi dengan klien. Saat kreativitas berproses, faktor eksternal seperti lingkungan kerja dan waktu ternyata memberikan dukungan pada kinerja kreatif para kreator.
\end{abstract}

Kata-kata kunci: Kreativitas; proses kreatif; kreator iklan; periklanan; biro iklan

\section{Construction of the meaning of creative process to creators in advertising agencies}

\section{ABSTRACT}

The article entitled construction of the meaning of creative processes to creators at advertising agencies intends to understand the meaning constructed by advertising creators about the creative process they experience when creating advertising work. The research question posed is how ad creators construct the creative processes they experience when working to create works. advertising according to their own views? The research method used is the qualitative method with the phenomenological tradition. The research subjects chosen were 12 ad creators in Bandung and Jakarta. Data collection was carried out by in-depth interview method. A number of questions posed are made in the form of an open questionnaire and take place in an informal setting. The results of the study reveal that the stages commonly passed in advertising in advertising agencies are gathering information, using information, brainstorming, developing ideas, conducting reviews, execution, artworking, presentation, and production. In the stages of making advertisements that the informants went through, it turned out that the creative process that took place within the informants was not only focused on one stage but spread over all stages with a distinctive stimulating style. Ad Creators have developed their creative processes based on various kinds of stimuli; namely a creative process based on stimulation of data referrals, a creative process based on stimulation of old experiences, a creative process based on stimulation of the exchange of ideas and arguments, a creative process based on stimulation of new experiences, a creative process based on unpredictable stimuli, a creative process based on stimulation of technical constraints, and a creative process based on stimulation. compromise with clients. When creativity is in process, external factors, such as work environment and time, actually provide support for the creative performance of the creators.

Keywords: Creativity; creative process; ad creator; advertising; advertising agency

Korespondensi: Dr. Teddy Kurnia Wirakusumah, M.I.Kom. Fakultas Ilmu Komunikasi Universitas Padjadjaran, Jalan Raya Jatinangor Km. 22 Sumedang.Email: teddy@unpad.ac.id 


\section{PENDAHULUAN}

Pertumbuhan penduduk, peningkatan kesejahteraan masyarakat, perkembangan teknologi dan kerjasama global saling memberikan pengaruh satu sama lain dalam menggerakkan roda perekonomian di berbagai belahan bumi. Dunia usaha makin berkembang menyediakan rupa-rupa barang konsumsi demi melayani beragam permintaan, memenuhi kebutuhan, memuaskan keinginan para pembeli. Pola-pola produksi secara massal semakin lazim. Jaringan transportasi kian mempermudah pergerakan dan perpindahan orang dan barang ke berbagai tempat. Aneka produk terus bertambah jumlah. Masing-masing saling bersaing memikat peminat. Persaingan semakin sengit.

Upaya promosi atau komunikasi pemasaran kian kompetitif lewat beragam alternatif. Bauran komunikasi pemasaran terdiri atas lima cara, salah satunya adalah periklanan. Periklanan adalah cara mengkomunikasikan produk dengan menggunakan media (Kotler \& Keller, 2016). Komunikasi bermedia artinya pertemuan antara produsen (pengiklan) dengan konsumen tidak berlangsung secara tatap muka. Di satu sisi kondisi ini memiliki kelebihan, namun di sisi lain memiliki kelemahan. Kelebihan iklan menurut Kotler dan Keller diantaranya: (1) Presentasi umum; (2) Tersebar luas; (3) Ekspresi yang lebih kuat (Kotler \& Keller, 2016)

Presentasi umum, yaitu memberikan semacam keabsahan pada produk dan menyarankan tawaran yang terstandardisasi. Karena banyak orang menerima pesan yang sama, pembeli mengetahui bahwa motif mereka untuk membeli produk tersebut akan dimaklumi oleh umum. Tersebar luas, maksudnya iklan dapat menggunakan media yang menjangkau khalayak secara luas dan memungkinkan penjual mengulang pesan berkali-kali. Sedangkan ekspresi yang lebih kuat, iklan memberikan peluang untuk mendramatisasi perusahaan dan produknya melalui penggunaan cetakan, suara, dan warna yang penuh seni. Periklanan berskala besar oleh seorang penjual menyiratkan hal yang positif tentang ukuran., kekuatan, dan keberhasilan penjual.

Kelemahan iklan yang berkomunikasi lewat media bersifat satu arah. Iklan tidak bisa bersifat memaksa. Berbeda dengan pertemuan tatap muka seperti penjualan personal, penjual dapat membuat pembeli merasa berkewajiban untuk mendengarkan pembicaraan yang berlangsung. Di dalam penjualan personal berlangsung hubungan yang hidup, langsung dan interaktif antara dua orang atau lebih. Masing-masing pihak dapat mengobservasi reaksi dari pihak lain secara lebih dekat dan akurat. Konfrontasi personal semacam itu tidak mungkin terjadi dalam periklanan. 
Khalayak mau memperhatikan atau tidak terserah pilihannya masing-masing. Padahal iklan sebagai salah satu bentuk komunikasi pemasaran tentunya memiliki tugas dan tujuan yang telah ditetapkan sebelumnya. Seperti kata Kotler dan Keller, komunikator pemasaran harus memutuskan tanggapan yang diharapkan dari audiens. Pemasar mungkin menginginkan tanggapan kognitif (cognitive), pengaruh pada sikap (affective), atau pengaruh pada perilaku (behavioral). Artinya, pemasar mungkin ingin memasukkan sesuatu ke dalam pikiran konsumen, mengubah sikap konsumen, atau mendorong konsumen untuk bertindak (Kotler \& Keller, 2016)

Jadi iklan punya tugas yang jelas, yaitu mencoba mengadakan perubahan pada diri konsumen. Apakah perubahan tersebut pada ranah cognitive seperti menciptakan kesadaran, meningkatkan pengetahuan konsumen tentang produk, memperkenalkannya lebih jauh, bahkan memberikan pengertian dan pemahaman yang menyeluruh tentang produk. Atau perubahan pada ranah affective, seperti menciptakan ketertarikan, membuat orang suka, menumbuhkan keinginan/minat, mengarahkan pilihan, menanamkan keyakinan atau kepercayaan terhadap produk. Bisa juga perubahan di ranah behavioral, seperti mengarahkan percobaan terhadap produk, menciptakan pembelian, bahkan meningkatkan pembelian berulang.

Membuat sadar, tahu, kenal, mengerti/ paham, tertarik, suka, ingin/berminat, memilih, yakin/percaya, mencoba, membeli dan pembelian secara berulang merupakan konsep "tahap kesiapan pembelian" yang khas dalam penetapan tujuan periklanan. Namun, bagaimana mungkin tujuan-tujuan yang dititipkan pada media iklan terpilih dapat dicapai kalau ternyata media tersebut diperhatikan saja tidak.

Komunikasi lewat media periklanan hanya berlangsung satu arah. Feedback tidak dapat diperoleh secara langsung. Padahal bagaimana khalayak bereaksi terhadap pesan yang dikirimkan sumber sangat bermanfaat dan diperlukan untuk mengevaluasi sejauhmana pencapaian tujuan komunikasi mencapai hasil. Iklan yang merupakan bentuk komunikasi bermedia memiliki keterbatasan dalam hal yang satu itu. Komunikasi lewat media periklanan tidak berlangsung secara timbal balik.

Di tengah persaingan usaha yang kian kompetitif iklan perlu bekerja keras untuk mendapat perhatian konsumen. Kerja iklan kian berat. Terlebih di era informasi yang semakin over communicated. Iklan bukan saja harus bersaing dengan iklan dari pesaing yang lain, ia juga harus berebut perhatian dengan beragam pesan yang melimpah ruah dari sejumlah sumber yang tak terhitung banyaknya. Kumar dan Gupta mengingatkan bahwa dinamika 
kekuatan telah berubah dalam iklim pemasaran, dan perusahaan harus memperhitungkan tidak hanya pesaing yang agresif tetapi juga anggota pelanggan dengan rentang perhatian terbatas (Kumar \& Gupta, 2016).

Rentang perhatian pengamat yang terbatas harus mampu diatasi. Iklan harus memiliki daya pikat. Saat pengamat terpikat, ia tengah melewati tahap pertama dalam penerimaan informasi yang disebut "sensasi”. Merebut tahapan awal dalam penerimaan informasi yang disebut sensasi bukanlah hal mudah. Dibutuhkan upayaupaya tertentu untuk memaksa, menjerat, atau membuat perhatian orang terpikat. Kreativitas menjadi kata kunci. Tanpa sentuhan kreativitas tak mudah bagi sebuah iklan untuk merebut tahapan awal penerimaan informasi yang disebut sensasi.

Stimuli berupa iklan yang ditangkap melalui indera ditafsirkan oleh pengamat. Memberikan makna pada stimuli indrawi disebut dengan "persepsi" merupakan proses lanjut dari sensasi. Suatu stimuli dapat melahirkan penafsiran yang beraneka ragam. Walaupun peristiwanya sama dapat saja orang memaknainya berbeda-beda. Selektivitas ternyata tidak hanya terjadi pada tahap awal penerimaan informasi saja (sensasi), ternyata saat memberikan penafsiran pun (persepsi) bersifat selektif.

Komunikastor media iklan sebagai penggagas komunikasi tidak boleh menitikberatkan pada upaya memikat perhatian belaka. Seorang komunikator media iklan harus kreatif memilih lambang, baik secara verbal maupun nonverbal dan memilih cara menghidangkan atau meyusun informasi agar dapat ditangkap dan ditafsirkan oleh khalayak dengan cara yang lebih mudah sehingga maksud-maksud masing-masing pihak bergerak menuju pengertian bersama yang lebih besar. Butuh upaya yang tidak sederhana agar maksud tersebut dapat terwujud. Perlu upaya kreatif untuk mewujudkan itu. Tanpa sentuhan kreativitas tak mudah bagi sebuah iklan untuk berbagi pengertian.

Selain itu, iklan diciptakan bukan sekadar untuk membuat orang memperhatikan dan kemudian memaknai informasi yang termuat di dalamnya. Produsen membuat iklan berharap bahwa setiap informasi yang termuat di dalamnya akan direkam dan tersimpan dalam ingatan konsumen selama mungkin. Ternyata ingatan pun bersifat selektif. Padahal bagaimana seseorang mengambil keputusan dalam masingmasing tahap kesiapan pembelian produk pada akhirnya akan sangat dipengaruhi oleh ingatannya mengenai produk. Oleh karena itu, seorang komunikator media iklan seyogyanya senantiasa memberikan perhatian pada iklannya dalam setiap bagian agar mampu disimpan lebih lama dalam ingatan pengamat. Tanpa 
sentuhan kreativitas tak mudah bagi sebuah iklan untuk disimpan dalam ingatan.

Kreativitas menjadi penting dalam periklanan. Tanpa sentuhan kreativitas tak mudah bagi sebuah iklan untuk merebut tahapan awal penerimaan informasi yang disebut sensasi. Tanpa sentuhan kreativitas tak mudah bagi sebuah iklan untuk berbagi pengertian dalam proses persepsi. Tanpa sentuhan kreativitas tak mudah bagi sebuah iklan untuk disimpan dalam ingatan. Tanpa sentuhan kreativitas kehadiran iklan bisa berakhir tanpa membawa guna. Tanpa sentuhan kreativitas iklan hanya membuangbuang percuma. Iklan kreatif di era informasi sekarang menjadi alternatif yang tidak bisa ditolak. Iklan kreatif kehadirannya mutlak dibutuhkan untuk mengatasi keterbatasan khalayak sasaran yang serba selektif dalam proses informasi; perhatian selektif, penafsiran selektif, dan ingatan selektif.

Kreativitas dipandang sebagai kunci sukses periklanan. Priest menyadari bahwa kreativitas dapat meningkatkan efektivitas dan efisiensi hingga sepuluh kali lipat. Sementara itu menurut Dyson dan Weaver selain pangsa pasar, kreativitas memiliki dampak terbesar kedua pada profitabilitas dan nilai merek dalam jangka panjang (Turnbull \& Wheeler, 2017).

Iklan kreatif tentunya lahir dari proses yang tidak sederhana. Banyak karya iklan kreatif telah dan pernah dilahirkan. Tetapi, kita tidak persis tahu bagaimana proses yang sebenarnya terjadi untuk melahirkan karya kreatif serupa itu. Proses yang berlangsung dalam penemuan iklan yang kreatif merupakan misteri yang menarik untuk diteliti.

Dalam prosesnya, kreativitas lazim didukung dengan menggunakan berbagai teknik pengembangan gagasan. Menurut Geschka teknik kreativitas dapat diklasifikasikan ke dalam dua perspektif yang berbeda. Pertama mengacu pada prinsip operasional, yaitu ideide dapat dihasilkan baik dengan merangsang intuisi atau dengan menggunakan pendekatan pemecahan masalah sistematis. Kedua mengacu pada mekanisme memicu gagasan, yaitu ide-ide merupakan hasil dari variasi dan pengembangan ide-ide yang ada atau dapat dipicu oleh konfrontasi dengan peristiwa, objek atau pikiran-pikiran yang independen dari masalah yang dihadapi (Wöhler \& Reinhardt, 2021).

Investigasi terfokus dari proses kreatif internal diperlukan, karena, seperti yang dikemukakan Hackley dan Kover, jika manajemen agensi dan klien dapat memahami proses dinamis pembuatan iklan secara lebih menyeluruh, mereka dapat memfasilitasi periklanan yang lebih efektif dan lebih kreatif (Stuhlfaut, 2011).

Rogers menekankan bahwa kreativitas adalah kecenderungan untuk mengaktualisasi 
diri, mewujudkan potensi, dorongan untuk berkembang dan menjadi matang, kecenderungan untuk mengekspresikan dan mengaktifkan semua kemampuan organisme (Munandar, 2012). Sedangkan Clark Moustakis seorang psikolog, menyatakan bahwa kreativitas adalah pengalaman mengekspresikan dan mengaktualisasikan identitas individu dalam bentuk terpadu dalam hubungan dengan diri sendiri, dengan alam, dan dengan orang lain (Munandar, 2012). Senada dengan Moustakis, Hulbeck menyebutkan tindakan kreatif muncul dari keunikan keseluruhan kepribadian dalam interaksi dengan lingkungannya (Munandar, 2012).

Sedangkan Barron menyatakan bahwa "kreativitas adalah kemampuan untuk menghasil-kan/menciptakan sesuatu yang baru". Begitu pula menurut Haefele "kreativitas adalah kemampuan untuk membuat kombinasikombinasi baru yang mempunyai makna sosial" (Munandar, 2012).

Berdasarkan uraian di atas maka penelitian ini dirumuskan sebagai berikut: bagaimana kreator iklan mengkontruksi realitas proses kreatif yang mereka alami? Oleh sebab itu penelitian ini bertujuan untuk menemukan dan menjelaskan bagaimana kreator iklan mengkonstruksi proses kreatif yang mereka alami ketika bekerja membuat karya iklan.

\section{METODE PENELITIAN}

Penelitian untuk mengungkapkan proses kreatif pada kreator iklan ini mengadopsi metodologi secara kualitatif. Oleh karena peneliti berupaya menggambarkan proses kreatif menurut pandangan mereka sendiri, tradisi yang digunakan pada penelitian ini adalah tradisi studi fenomenologi. Studi dengan pendekatan fenomenologi berupaya untuk menjelaskan makna pengalaman hidup sejumlah orang tentang suatu konsep atau gejala, yang dalam hal ini adalah kreator iklan.

Sesuai dengan persyaratan pemilihan subjek dalam studi fenomenologi, subjek dalam penelitian ini adalah individu yang telah mengalami fenomena yang akan diteliti dan mampu mengartikulasikannya (Creswell, 2013). Proses kreatif dalam penelitian ini digali dari kreator iklan yang telah menghasilkan karya iklan di berbagai media. Subjek penelitian tersebut dijadikan informan utama atau sumber data utama atau partisipan. Subjek dipilih secara purposif berdasarkan aktivitas dan kesediaan mereka untuk mengeksplorasi dan mengartikulasikan penga-laman mereka secara sadar

Pengumpulan data dalam penelitian ini dilakukan dengan metode wawancara mendalam dan observasi terhadap subjek penelitian atau informan, juga didukung rujukan 
data sekunder berupa literatur dan sumber data penunjang. Wawancara dilakukan terhadap 12 orang kreator dari 5 biro iklan yang terdiri dari 1 orang Creative Director dari Mitramark, 2 orang Creative Director dari Fortune Indonesia, 2 orang Creative Director dari Artek'n Partner Advertising, 1 orang Creative Director, 3 orang Art Director dan 2 orang Graphic Designer dari Dwi Sapta, dan 1 orang Art Director dari Visual Inovasi Profindo. Pemilihan kreator ditempuh dengan memperhatikan aspek: (1) lama bekerja di dalam industri kreatif lebih dari 10 tahun; (2) memiliki reputasi yang cukup baik; dan pernah mendapatkan penghargaan (3) produktivitas berkarya cukup tinggi dan terlibat dalam lebih dari 20 karya iklan.

Analisis data fenomenologis berlangsung melalui metodologi reduksi, analisis pernyataan tertentu dan tema, serta mencari makna-makna yang lain. Peneliti juga mengesampingkan praduga, bracketing dari pengalamannya, dan bergantung pada intuisi, imajinasi dan struktur universal untuk mendapatkan gambaran dari pengalaman. Oleh karena data penelitian ini berupa data kualitatif maka terdapat tiga alur kegiatan yang dapat dilakukan secara bersamaan, yaitu: (1) reduksi data; (2) penyajian data; dan (3) penarikan kesimpulan.

\section{HASIL DAN PEMBAHASAN}

Para informan, memiliki pengalaman menjadi kreator iklan tidak hanya pada biro iklan yang menjadi tempat bekerjanya saat ini saja, melainkan pernah menjejakkan kakinya di berbagai biro iklan lain sebelumnya. Hal ini dapat kiranya dipandang sebagai bukti pengakuan atas prestasinya dan keluasan akan pengalaman, karena masing-masing tempat kerjanya terdahulu dan sekarang akan memberikan kemampuan dan kekayaan perspektif dalam berpikir, memandang permasalahan, memecahkan dan mengambil keputusan. Kemampuan tersebut menjadi penting keberadaannya dalam mengkonstruksi proses kreatif yang mereka alami.

Pekerjaan membuat iklan diterima oleh biro iklan dari klien (pengiklan) secara garis besar terdiri dari dua cara yang pertama melalui penunjukkan langsung yang kedua melalui mekanisme pitching. Dalam penunjukkan langsung, klien menunjuk dan menyerahkan pekerjaan iklannya terhadap biro iklan tertentu. Hal ini biasanya terjadi karena antara klien dan biro iklan sudah terjalin kerjasama yang relatif tetap, atau bisa terjadi pula karena volume pekerjaan relatif kecil. Sedangkan melalui mekanisme pitching, klien biasanya mengundang beberapa biro iklan untuk menghadiri briefing. Dalam pertemuan tersebut diutarakan mengenai karakteristik produk yang akan ditawarkan ke pasar, target yang ingin dicapai, karakteristik pesaing, anggaran yang 
tersedia dan segala informasi yang terkait. Setelah itu setiap biro iklan yang diundang diharuskan menyusun rencana periklanan yang tepat sesuai target yang ingin dicapai. Rencana tersebut harus dipresentasikan dalam pitching sesuai jadwal yang disepakati, meliputi strategi kreatif, strategi media serta rencana pembiayaan. Berdasarkan pitching tersebut, klien akan menetapkan biro iklan yang akan mendapatkan pekerjaan tersebut. Baik melalui penunjukkan langsung ataupun melalui mekanisme pitching tahap pembuatan iklan yang dilalui tetap sama. Perbedaannya, pada penunjukkan langsung tahap tersebut dikerjakan setelah akad penyerahan pekerjaan dari klien ke biro iklan diputuskan, sedangkan pada mekanisme pitching tahapan tersebut sudah dimulai sebelum akad penyerahan pekerjaan dari klien ke biro iklan diputuskan.

Tahapan pembuatan iklan di setiap biro iklan tempat bekerja informan secara prinsip melalui tahapan serupa, yaitu: (1) Mengumpulkan data dan informasi; (2) Menggunakan data dan informasi; (3) Brainstorming; (4) Mengembangkan gagasan; (5) Review; (6) Eksekusi; (7) Membuat artwork/storyline; (8) Presentasi; dan (9) Produksi.

Tahap awal pembuatan iklan diawali dengan pengumpulan data dan informasi yang diperoleh dari klien atau pihak lain berupa data sekunder. Data dan informasi yang dikumpulkan biasanya menyangkut informasi produk, sasaran, media dan kompetitor. Dalam kasus-kasus tertentu, jika data yang diperlukan tidak tersedia adakalanya data primer melalui riset kecil ditempuh.

Data dan informasi yang sudah terkumpul dibagikan kepada seluruh anggota tim kreatif sebagai bahan untuk digunakan dalam merumuskan gagasan yang akan disampaikan pada sesi braintorming. Masing-masing anggota berupaya memahami bahan secara individual. Dalam tahapan inilah proses kreatif pembuatan iklan pada diri informan dimulai.

Tahap berikutnya adalah brainstorming. Brainstorming dilaksanakan untuk menjaring gagasan-gagasan yang diajukan anggota tim kreatif. Dalam pelaksanaan brainstorming, walaupun pada awalnya adalah pengumpulan gagasan hasil kreativitas tiap anggota tim namun pada tahap ini proses kreatif terus berlanjut dan lebih bersifat kolektif daripada individual.

Forum brainstorming biasanya menyepakati apa yang akan disampaikan atau what to say. Setelah mendapatkan what to say atau platform komunikasi, langkah berikutnya adalah menemukan how to say. Untuk mendapatkannya masing-masing kreator melanjutkan proses kreatifnya secara individual sesuai spesialisasi keahliannya. Copywritter lebih berkonsentrasi pengolahan naskah verbal. Art Director lebih memusatkan diri pada 
penyajian visual. Computer Graphic/Designer lebih ke pengolahan layout dan komputer digital, Visualizer lebih menekuni penyediaan illustrasi, gambar storyboard, atau foto. Pada tahap ini umumnya masing-masing kreator menghasilkan beberapa alternatif.

Tahap berikutnya, semua karya alternatif mendapatkan review. Apakah seluruh alternatif akan diajukan atau tidak. Ada kemungkinan dalam tahap ini beberapa perbaikan perlu dilakukan untuk penyempurnaan, tapi biasanya tidak begitu mendasar. Hasil review akan memutuskan alternatif karya mana saja yang akan dieksekusi untuk diajukan pada klien.

Pekerjaan yang telah dieksekusi masih berupa final design untuk print ad dan masih berupa storyboard untuk TVC. Untuk menjadi karya yang ready copy (siap cetak) maka karya final design harus diubah dalam bentuk artwork. Dalam beberapa pekerjaan tertentu adakalanya terdapat hambatan teknis yang tidak memungkinkan hasil produksi akhir sama persis dengan desain final. Demikian juga untuk iklan TVC, untuk kasus-kasus tertentu storyboard saja tidak cukup, tapi sudah berbentuk animated graphic atau storylinel stylomatic (atau bahkan lebih; sudah berbentuk tiruan TVC sebenarnya). Perubahan format ini seringkali memuat masalah-masalah teknis yang membutuhkan perbaikan untuk menghasilkan karya yang maksimal. Upaya-upaya untuk mengatasi permasalahan ini seyogyanya ditempuh sebelum presentasi dilakukan untuk menghindari masalah yang muncul kemudian. Untuk mengatasinya terkadang proses kreatif masih diperlukan pada tahap ini.

Setelah semuanya siap, maka karya akan dipresentasikan ke klien. Presentasi yang dilakukan pertamakalinya dapat menghasilkan kemungkinan diterima atau ditolak. Penerimaan berarti tahap awal pekerjaan yang sesungguhnya dan menyeluruh baru akan dimulai. Sedangkan penolakan biasanya disertai arahan untuk melakukan perubahan mendasar. Dengan demikian, proses kreatif dimulai lagi dari awal.

Jika presentasi yang dilakukan berdasarkan pekerjaan yang diterima melalui mekanisme penunjukkan langsung, hasilnya bisa berupa persetujuan hingga karya siap diproduksi atau beberapa perubahan kecil. Hal ini dimungkinan karena sepanjang tahapan yang berlangsung komunikasi dengan klien terus terjalin. Betapapun kecilnya, jika terdapat perubahan maka proses kreatif masih berlanjut.

Karya rancangan para informan yang sudah disetujui klien pada akhirnya akan diproduksi dalam bentuk print ad atau TVC. Kegiatan 0produksi biasanya diserahkan pada pihak lain. Untuk print ad biasanya diserahkan ke percetakkan atau media cetak, sedangkan konsep TVC ke PH (production house).

Proses kreatif yang terjadi saat informan 
berkarya pada hakekatnya berlangsung dalam pikiran dan ternyata tidak mudah bagi informan untuk mengkonstruksi kembali secara terinci apa yang sesungguhnya terjadi saat peristiwa tersebut berlangsung. Namun apa yang mereka alami, mereka pikirkan dan mereka lakukan secara sadar saat proses kreatif tersebut berlangsung pada umumnya dapat terungkapkan dengan cukup baik.

Dalam upayanya menghasilkan karya iklan yang kreatif prosedur standar yang harus dilalui informan tahap-tahapan jelas, seperti telah dijabarkan sebelumnya. Dalam tahapan-tahapan pembuatan iklan yang dilalui oleh informan, ternyata proses kreatif yang berlangsung dalam diri informan tidak hanya terpusat pada salah satu tahap saja tapi tersebar hampir di banyak tahapan yang masing-masing didasari corak rangsangan yang khas. Untuk mempermudah penjelasan masing-masing jenis rangsangan diberikan nama berbeda, yaitu (1) Rangsang rujukan data; (2) Rangsang pengalaman lama; (3) Rangsang pertukaran gagasan \& argumen;
(4) Rangsang pengalaman baru; (5) Rangsang tidak terduga; (6) Rangsang kendala teknis; dan (7) Rangsang kompromi dengan klien.

Ragam rangsangan yang dialami kreator bisa berbeda-beda. Ada jenis rangsangan yang dialami sama oleh semua kreator. Ada jenis rangsangan yang dialami oleh sebagian besar kreator. Ada pula jenis rangsangan yang hanya dialami oleh sebagian saja atau bahkan hanya sebagian kecil kreator. Proses kreatif berbasis rangsang rujukan data ternyata dialami sama oleh semua kreator. Sementara itu, rangsang pengalaman lama, rangsang pengalaman baru dan rangsang kompromi dengan klien dialami oleh sebagian besar kreator. Kemudian, rangsang pertukaran gagasan dan argumen hanya dialami oleh sebagian kreator. Sedangkan rangsang tidak terduga dan rangsang kendala teknis hanya dialami sebagian kecil kreator. Masing-masing jenis rangsangan yang dialami dan diungkapkan oleh setiap kreator beserta variasi terjadinya digambarkan seperti tersaji dalam tabel 1 .

\section{Tabel 1 Analisis Pernyataan dan Tema}

\begin{tabular}{|c|c|c|c|c|c|c|c|c|c|c|c|c|c|}
\hline & \multirow[t]{2}{*}{ Jenis Rangsang Proses Kreatif } & \multicolumn{12}{|c|}{ Informan Kreator Iklan } \\
\hline & & 1 & 2 & 3 & 4 & 5 & 6 & 7 & 8 & 9 & 10 & 11 & 12 \\
\hline 1 & Rujukan Data, & $\mathrm{V}$ & $\mathrm{V}$ & V & $\mathrm{V}$ & $\mathrm{V}$ & V & $\mathrm{V}$ & V & $\mathrm{V}$ & V & $\mathrm{V}$ & $\mathrm{V}$ \\
\hline 2 & Pengalaman Lama, & $\mathrm{V}$ & $\mathrm{V}$ & V & V & $\mathrm{V}$ & - & $\mathrm{V}$ & V & $\mathrm{V}$ & V & $\mathrm{V}$ & $\mathrm{V}$ \\
\hline 3 & Pertukaran Gagasan \& Argumen, & $\mathrm{V}$ & $\mathrm{V}$ & $\mathrm{V}$ & $\mathrm{V}$ & - & - & - & - & $\mathrm{V}$ & - & - & $\mathrm{V}$ \\
\hline 4 & Pengalaman Baru, & $\mathrm{V}$ & V & $\mathrm{V}$ & - & - & V & $\mathrm{V}$ & - & $\mathrm{V}$ & $\mathrm{V}$ & $\mathrm{V}$ & $\mathrm{V}$ \\
\hline 5 & Tidak Terduga, & $\mathrm{V}$ & $\mathrm{V}$ & $\mathrm{V}$ & $\mathrm{V}$ & - & - & - & - & - & - & - & - \\
\hline 6 & Kendala Teknis & - & $\mathrm{V}$ & $\mathrm{V}$ & - & - & - & - & - & - & - & - & - \\
\hline 7 & Kompromi dengan Klien & $\mathrm{V}$ & V & $\mathrm{V}$ & V & - & V & $\mathrm{V}$ & $\mathrm{V}$ & V & - & - & $\mathrm{V}$ \\
\hline
\end{tabular}

Sumber : Analisis hasil penelitian, 2020 
Jenis proses kreatif pertama disebut proses kreatif berbasis rangsang rujukan data. Data sangat berperan menjadi titik awal proses kreatif pembuatan iklan. Seluruh informan tanpa kecuali mengawali proses kreatifnya berdasarkan rangsang rujukan data yang tersedia. Iklan dibuat dengan tugas yang jelas. Ia akan bekerja untuk melayani klien yang berharap tujuannya tercapai. Iklan membutuhkan sentuhan keindahan, tapi iklan tidak boleh menjadi semacam media ekspresi seniman. Untuk bekerja dengan baik, iklan dibuat harus berdasarkan data yang jelas.

Gagasan awal secara individual yang diperoleh melalui proses kreatif berbasis pada rujukan data ini merupakan bahan yang sangat bermanfaat untuk bahan perbincangan dalam forum brainstorming. Semakin lengkap data yang dimiliki semakin banyak pilihan bagi kreator untuk mengawali langkah darimana proses kreatifnya dimulai. Walaupun selalu ada kemungkinan tidak semua data yang tersedia akan dimanfaatkan, karena bagi kasus tertentu atau bagi informan tertentu hanya data-data tertentu saja yang lebih dominan diperlukan.

Gagasan yang diperoleh melalui proses kreatif berbasis pada rujukan data ini juga oleh informan digunakan pada tahap pengembangan gagasan pasca brainstorming untuk menemukan how to say. Kalau datanya lengkap, mennyepakati big idea jadi lebih mudah. Bagi copywriter apa yang akan diutarakan bisa lebih fokus. Bagi Art Director, bagaimana secara visual pesan disampaikan pun jadi lebih mudah. Misalnya jika targetnya anak-anak, kreator bisa milih apakah childis, heroic, khayal, imajinatif, atau kreatif. Kalau untuk remaja pilihanya bisa hiperbolis, agresif, petualangan, humor, genit, ceria, atau praktis. Bagi target dewasa biasanya lebih rasional, dramatis, berisi konflik, logis, evaluatif, dan sensitif. Sedangkan untuk khalayak target berusia tua, mungkin lebih santun, elegan, bermuatan gaya hidup, simbolik, atau konvensional.

Proses kreatif berbasiskan rujukan data juga digunakan oleh sebagian informan sebagai bahan pertimbangan agar saat presentasi dengan klien tidak mengalami hambatan yang berarti. Gagasan yang berangkat dari data akan mempermudah memberikan alasan yang masuk akal dan dapat dipertanggungjawabkan Selain itu juga akan mempermudah evaluasi, karena ukuran-ukuran yang ditetapkan berpijak pada fakta yang konkrit. Proses kreatif berbasis data sejalan dengan anjuran Shimp mengenai strategi pesan kreatif. Strategi pesan kreatif terkadang disebut platform kreatif, mewakili cara kerja internal dari keseluruhan strategi periklanan. Platform kreatif untuk sebuah merek berangkat dari data-data penting tentang pasar sasaran, identifikasi pesaing dan diringkas menjadi satu pernyataan yang diklasifikasikan 
sebagai proposisi nilai atau pernyataan posisi. Pernyataan pemosisian adalah satu-satunya gagasan terpenting yang ingin dipegang oleh merek dalam benak konsumen. Ini juga memperhitungkan bagaimana pesaing memposisikan merek mereka. Pikiran dan perasaan konsumen tentang merek harus menonjol dibandingkan dengan penawaran kompetitif dan harus memotivasi pelanggan atau prospek untuk mencoba merek. Platform kreatif terdiri dari (1) definisi pasar sasaran; (2) identifikasi persaingan utama; (3) pilihan pernyataan pemosisian; dan (4) tawaran alasan mengapa (Shimp \& Andrews, 2018).

Jenis proses kreatif kedua disebut proses kreatif berbasis rangsang pengalaman lama. Apa yang yang pernah dikerjakan berikut semua pengalaman yang pernah dialami oleh informan terbuka kemungkinannya sebagai pemicu kreativitas untuk berproses. Beberapa informan secara terus terang mengatakan bahwa bukan masalah jika proses kreatif dirangsang berdasarkan karya-karyanya terdahulu. Menurut sebagian informan gagasan dikembangkan lewat cara berpikir yang unik. Tidak ada yang benar-benar baru di dunia ini, yang bisa dilakukan hanyalah kemampuan mengurai elemen dan mengga-bungkannya lagi menjadi bentuk yang baru. Jadi apa yang pernah dikerjakan sebelumnya atau karya yang pernah dibikin orang tetap berguna dan bisa saja jadi rujukan. Renzulli menyatakan bahwa kreativitas sebagai kemampuan umum untuk menciptakan sesuatu yang baru, sebagai kemampuan untuk memberikan gagasan-gagasan baru yang dapat diterapkan dalam pemecahan masalah, atau sebagai kemampuan untuk melihat hubunganhubungan baru antara unsur-unsur yang sudah ada sebelumnya (Munandar 2009).

Beberapa informan lain tidak terlalu mengandalkan karyanya terdahulu namun lebih memilih rangsang pengalaman lama dalam bentuk pengetahuan teoritis yang pernah dimilikinya dari hasil belajar, seperti mindmapping, brainstorming, ask why, ask how if, dan seterusnya. Selain itu proses kreatif berbasis rangsang pengalaman lama ini adakalanya didasarkan pada temuantemuan yang pernah digagas sebelumnya hanya belum sempat digunakan. Yang menarik seluruh informan tanpa terkecuali adalah orang-orang yang memiliki catatan gagasan. Mereka menyadari bahwa menjadi kreatif adalah pilihan hidupnya. Oleh karena itu, mereka membuat jalan menuju kreativititas dengan memprogramkan kreativitas itu sendiri, menciptakan suatu kondisi demi mengalirnya kreativitas, dan gagasan bisa bisa muncul dimana saja, kapan saja. Sebuah catatan gagasan menjadi penting sebagai pengganti ingatan, yang mungkin diperlukan saat dibutuhkan.

Jenis proses kreatif ketiga disebut proses 
kreatif berbasis rangsang pertukaran gagasan $\&$ argumen. Fenomena ini sangat tampak nyata dalam pelaksanaan brainstorming. Walaupun pada awalnya brainstorming merupakan pengumpulan gagasan hasil kreativitas tiap anggota tim peserta, namun tatkala gagasan-gagasan diutarakan kerapkali merangsang hadirnya gagasan-gagasan baru. Beberapa gagasan yang serupa dilakukan pendalaman, dipertajam hingga lebih fokus. Gagasan-gagasan yang kuat didiskusikan lebih komprehensif hingga mengerucut jadi sebuah gagasan tunggal yang kreatif tapi tetap komunikatif. Saat pembahasan, ide bergerak dari satu orang ke orang lain dan pada akhirnya tidak bisa diidentifikasi lagi pemiliknya. Gagasan-gagasan individual bergerak ke arah kolektif. Hingga kita menemukan pesan apa yang akan disampaikan berikut arahan cara menyam-paikannya dengan kreatif

Brainstorming adalah wahana yang sangat demokratis, berdasarkan pengakuan informan semua yang terlibat memiliki hak yang sama. Tidak ada pihak yang dominan. Kalau pun ada dominasi biasanya lebih karena gagasannya yang kuat, sehingga semua bergerak ke sana.

Reiter-Palmon \& Robinson meneliti bagaimana proses kognitif mempengaruhi kreativitas terjadi di dalam tim. Mereka mempresentasikan model multi-level untuk proses pemecahan masalah secara kreatif dalam tim, termasuk fase awal identifikasi dan konstruksi masalah. Individu dalam tim cenderung untuk memiliki perbedaan masalah representasi, yang akan menghasilkan dalam berbagai cara dalam membingkai masalah yang sama. Perbedaan ini cenderung diungkapkan dalam tim secara beragam. Selanjutnya, individu dalam tim akan cenderung menjadi sadar dari ini perbedaan pendapat dan mengarah pada solusi terbaik (Reiter-Palmon, 2017).

Proses kreatif berbasiskan rangsang pertukaran gagasan dan argumen kerap terjadi pula pada tahap pengembangan gagasan untuk menemukan how to say. Hanya pertukaran gagasan yang berlangsung biasanya tidak dalam sebuah pertemuan formal. Beberapa informan merangsang gagasannya lewat beberapa cara yang agak mirip, lewat interaksi, ngobrol, ngopi bareng dengan orang lain dapat memberikannya inspirasi, atau networking dengan beberapa narasumber dari bidang lain yang bukan biro iklan tapi berkaitan atau obrolan berbagi pengalaman dengan sesama kreator iklan sering memberi masukan berharga untuk ide kreatif.

Kristensson dan Norlander melaporkan hasil penelitian tentang kinerja kreatif dalam kelompok kecil. Desain eksperimental digunakan untuk menilai efek Group Communication Support System (GCSS) dan kegunaan yang dirasakan pada produk kreatif dan proses kreatif. Obrolan, konferensi video, 
dan grup tatap muka dibandingkan. Hasil analisis menunjukkan bahwa kelompok tatap muka membangkitkan hasil yang lebih kreatif daripada dua kelompok lainnya. Semakin nyata kondisinya, semakin lancar ide. Grup konferensi video mendapatkan skor yang jauh lebih rendah dalam hal inkubasi dalam proses kreatif. Peserta dalam kelompok tatap muka melaporkan diri mereka lebih puas dengan produk dan proses mereka daripada peserta dalam kelompok yang dimediasi komputer. Studi tersebut menunjukkan bagaimana GCSS mempengaruhi kinerja kreatif (Kristensson \& Norlander, 2003).

Jenis proses kreatif keempat disebut proses kreatif berbasis Rangsang Pengalaman Baru. Upaya-upaya untuk menemukan how to say perlu mempertimbangkan trend yang terjadi masyarakat, itu sebabnya proses kreatif yang berlangsung pada tahapan ini sering melibatkan upaya-upaya menstimulasi diri dengan pengalaman-pengalaman baru. Pekerjaan pada tahap mengembangkan gagasan untuk menemukan how to say adalah pekerjaan yang paling memakan waktu. Masing-masing kreator melanjutkan proses kreatifnya secara individual sesuai spesialisasi keahliannya sambil update pengalaman baru. Komunikasi yang intens antar anggota tim juga harus terus dibangun agar kesatuan arah tetap terjaga sesuai platform komunikasi yang sudah ditetapkan bersama. Cara menstimuli pengalaman baru yang ditempuh informan sangat beragam. Ada yang mengamati pengalaman hidup target keseharian, ngobrol dengan banyak pihak, jalan-jalan ke mall, ngopi bareng, nonton film adalah beberapa pilihan yang biasa dilakukan para informan. Proses kreatif berbasis rangsang pengalaman baru lazim pula diperoleh dengan mengapresiasi karya orang lain terkini, melalui buku, internet dan sumber-sumber referensi up to date lainnya.

Keterbukaan mencari dan mendapat pengalaman baru sepertinya menjadi ciri kreator untuk mendukung proses kreatifnya. Seperti kata Sánchez-Ruiz, bukti lama dan baru menunjukkan bahwa kecerdasan berkontribusi pada kreativitas hingga tingkat kecerdasan tertentu, tetapi yang pertama tidak cukup untuk yang terakhir. Ciri kepribadian, khususnya keterbukaan terhadap pengalaman, adalah kunci kreativitas, sementara yang lain bersifat spesifik domain (Sánchez-Ruiz, 2020).

Pendapat ini didukung Carl Rogers yang mengungkapkan bahwa tiga kondisi pribadi kreatif ialah: (1) keterbukaan terhadap pengalaman; (2) kemampuan untuk menilai situasi sesuai dengan patokan pribadi seseorang (internal locus of evaluation); dan (3) kemampuan untuk bereksperimen, untuk "bermain" dengan konsep-konsep. Setiap orang yang memiliki ketiga ciri ini kesehatan 
psikologisnya sangat baik. Orang ini berfungsi sepenuhnya, menghasilkan karya-karya kreatif, dan hidup secara kreatif. Ketiga ciri atau kondisi tersebut juga merupakan dorongan dari dalam (internal press) untuk berkreasi (Munandar, 2012).

Jenis proses kreatif kelima disebut proses kreatif berbasis rangsang tidak terduga. Para informan sejak awal memilih pekerjaan sebagai kreator iklan karena didasarkan minat. Motivasi yang kuat tercermin dalam cara menghargai pekerjaan sebagai sesuatu yang paling menarik. Mereka melakukan apa yang mereka ingin hasilkan karena mereka ingin mengambil kesempatan yang sebaik-baiknya untuk melakukan pekerjaan yang mereka senangi. Oleh karena itu, proses kreatif mereka tidak hanya terpaku berlangsung saat berhadapan dengan pekerjaan, tapi bisa berlangsung dimana saja, kapan saja dan dirangsang oleh apa saja, bahkan oleh sesuatu yang tidak terduga. Proses kreatif berbasis rangsang tidak terduga adakalanya berbuah manfaat bagi pekerjaan yang tengah informan hadapi. Hasilnya bukan sekadar pencerahan tapi lebih berupa kejutan.

Dalam Ilmu Psikologi, proses kreatif berbasis rangsang tidak terduga disebut dengan pengalaman "Aha" dan sering berlangsung saat pikiran melepaskan diri dari pekerjaan dan justru menjadi jalan keluar yang diharapkan. Meskipun pengalaman wawasan seperti ini telah lama dikenal, inti dari pengalaman "Aha", yang mencerminkan perubahan tiba-tiba di otak yang menyertai solusi wawasan, sebagian besar masih belum diketahui. memberikan gambaran umum penelitian tentang hubungan antara pengalaman Aha dan keakuratan solusi pemecahan masalah. Hubungan antara solusi yang benar dan pengalaman Aha jelas ada dalam literatur. Namun, kekuatan dan frekuensi pengalaman Aha tampaknya bervariasi antar individu dan dapat dimanipulasi (Danek \& Salvi, 2018).

Jenis proses kreatif keenam disebut proses kreatif berbasis rangsang kendala teknis. Perubahan format pada tahap pekerjaan artworking dan pembuatan storyline kerapkali memuat masalah-masalah teknis yang membutuhkan pemecahan kreatif untuk mengatasinya atau mengantisipasi sebelumnya. Masalah yang sering muncul pada print ad umumnya masalah resolusi dan perubahan warna. Kalau masalah resolusi mau tidak mau saat desain dirancang graphic designer sudah harus mempertimbangkan masalah teknis yang bakal muncul. Ilustrasi dan foto sejak awal harus dipersiapkan dengan resolusi yang cukup. Kalau masalah pewarnaan biasanya dikonsultasikan dengan yang mahir colour management.

Sedangkan untuk TVC, durasi sering jadi masalah. Saat masih dalam bentuk storyboard pertimbangan durasi sepertinya udah cukup 
tapi saat diubah jadi audio visual tampak jadi bertele-tele. Beberapa footage visual besar kemungkinan perlu ditambahkan. Sedangkan untuk audionya, jika tanpa verbal biasanya tidak terlalu serius, tapi kalau memuat aspek verbal, maka keativitas copywriter masih harus berproses untuk melakukan penyesuaian.

Proses kreatif berbasis rangsang kendala teknis lazim pula berlangsung saat tiba pada pekerjaan produksi, khususnya iklan tv. Pekerjaan produksi untuk TVC biasanya diserahkan pada pihak lain yaitu $\mathrm{PH}$ (production house). Visualizer yang membuat storyboard pada dasarnya adalah orang yang terbiasa bekerja dengan gambar statis. Saat bertemu sutradara yang memang terlatih dan fasih dengan bahasa film biasanya memberi masukkan untuk perubahan. Masukkan perubahan tentunya dilakukan demi solusi terbaik. Jika pertimbangannya bagus maka perlu direspon dengan melibatkan persetujuan klien.

Penelitian terbaru menantang anggapan bahwa kendala biasanya menghambat kreativitas. Kinerja kreatif, baik untuk individu maupun tim, sebenarnya dapat mengambil manfaat dari kendala. Profesional kreatif telah mencatat nilai dan pentingnya kendala untuk meningkatkan kreativitas individu dan tim (misalnya Mayer dan Tharp). Bahkan, Stokes menggambarkan kendala sebagai "hambatan yang mengarah pada terobosan" dalam berbagai profesi kreatif, dari desain produk dan arsitektur hingga seni visual dan musik (Rosso, 2014).

Jenis proses kreatif ketujuh atau terakhir disebut proses kreatif berbasis rangsang kompromi dengan klien. Biro iklan dan klien adalah dua pihak yang tengah bekerjasama dan membentuk berbagai kesepakatan yang saling menguntungkan bagi kedua belah pihak. Pembuatan iklan kreatif hanya salah satu dari kesepakatan yang lebih besar. Dibutuhkan sikap kompromistis antara kedua belah pihak. Bagi kreator berusaha memahami apa yang diinginkan klien, sedangkan dari pihak klien dibutuhkan kesadaran untuk membiarkan professional mengerjakan tugas mereka

Adanya benturan kepentingan seringkali justru baru terbuka saat presentasi, klien memiliki keberatan terhadap karya yang ditawarkan. Menurut beberapa informan hal tersebut dimungkinkan karena beberapa sebab. Keberatan yang paling sering terjadi karena secara mendadak brief klien berubah akibat kondisi pasar yang dinamis. Adakalanya juga keberatan terhadap karya disebabkan karena adamya perbedaan persepsi dalam hal peggunaan istilah dan dan tak jarang pula karena adanya perbedaan selera.

Jika diperhatikan hal-hal yang menjadi penyebab keberatan klien, tampak kurangnya upaya kompromi terhadap apa yang diinginkan 
klien. Sesungguhnya permasalahan di atas bisa di bisa dihindari jika sejak awal proses kreatif berbasiskan rangsang kompromi dengan klien. Munculnya keberatan atau penolakan karena belum ada komunikasi yang jelas dengan klien. Umumnya gagasan bisa diterima dan dikembangkan selama ada komunikasi yang bagus dengan klien.

Dalam hal keterampilan, komunikasi adalah hal yang harus dikuasai setiap Akun Eksekutif. Orang-orang akun membutuhkan integritas dan penilaian yang berlimpah untuk menavigasi masalah dan hubungan yang semakin kompleks yang menjadi ciri bisnis komunikasi pemasaran dan periklanan. Orang-orang yang hebat memiliki kualitas lain: kesabaran, disiplin, bekerja di bawah tekanan, selera humor, ketelitian, rasa memiliki, semangat kolaborasi, kepercayaan diri, kemampuan memahami konteks, orientasi layanan. Semua ini sangat penting (Solomon, 2016).

Dalam uraian sebelumnya telah dijabarkan bagaimana proses kreatif yang berlangsung secara internal di dalam diri informan. Berikutnya akan diulas bagaimana faktor eksternal memberikan kontribusi dalam proses kreatif informan. Faktor-faktor eksternal yang disadari dan diungkapkan oleh informan memberikan andil dalam proses kreatif yang mereka tempuh terkait dengan lingkungan kerja dan waktu.
Lingkungan tempat bekerja merupakan salah satu faktor yang membawa dampak cukup besar dalam aktivitas kreativitas para informan. Baik lingkungan fisik maupun lingkungan sosial memberi dukungan terhadap aktivitasnya untuk berkarya. Tata ruang yang nyaman, fasilitas kerja yang memadai, koleksi pustaka yang lengkap memberi banyak dukungan terhadap kreativitas informan Seluruh informan tanpa kecuali menyatakan bahwa lingkungan tempatnya bekerja sangat mendukung terhadap aktivitasnya berkarya. Hal ini sejalan dengan penelitian Fuss dan Daniel yang mengungkapkan bahwa persiapan, sikap dan komitmen dalam mempersiapkan ruang kreatif "sebagai tempat perlindungan kreatif" diperlukan untuk menciptakan lingkungan ruang internal yang "mempesona". Ada halhal fisik dan hal-hal yang sesuai yang diatur sedemikian rupa di studio seperti gambargambar di sekitar untuk merangsang ide-ide (Fuss \& Daniel, 2020).

Bagi orang-orang tertentu mungkin membutuhkan suasana khusus agar dapat menghasilkan gagasan yang terbaik. Mengenai hal ini, beberapa informan punya pendapat yang berbeda. Ada yang lebih suka bekerja di ruangan sendiri atau di meja kesukaan yang sudah ditata sesuai kebutuhan. Ada yang lebih mementingkan suasana yang tenang tidak riuh. Ada yang merasa perlu mendengarkan musik 
kesukaan selama bekerja. Ada ada pula yang tidak terlalu memiliki ketergantungan pada suasana, karena sudah terbiasa dan membiasakan diri bekerja berdasarkan manajemen proses dan waktu deadline. Baginya ketergantungan pada suasana dapat merugikan produktivitas.

Selain lingkungan kerja, waktu bekerja juga memberikan andil dalam proses kreatif informan. Waktu bekerja informan secara terjadwal seperti lazimnya tempat bekerja yang lain memiliki waktu tertentu. Ada yang terjadwal jam 08.00-16.00 dan ada pula yang terjadwal jam 08.30-16.30. Namun di semua tempat bekerja informan waktu kerja tersebut memiliki fleksibilitas yang agak unik. Pada saat-saat tertentu untuk jenis pekerjaan tertentu terkadang menuntut waktu yang lebih panjang dari waktu terjadwal. Misalnya seseorang harus menempuhnya hingga larut malam, maka kesokan harimya yang bersangkutan boleh datang agak siang.

Berbagai perusahaan telah lama menggunakan berbagai pendekatan untuk mengatur waktu karyawan mereka untuk tugastugas kreatif dan tugas rutin guna meningkatkan kinerja inovatif. Dalam makalahnya dilaporkan tentang pengaruh jadwal kerja otonom terhadap kinerja kreatif dan rutin individu. Hasil eksperimen laboratorium mengungkapkan bahwa sementara kinerja rutin rata-rata tidak dipengaruhi oleh otonomi jadwal, pengaruh otonomi jadwal pada kinerja kreatif tergantung pada impulsif subjek. Ada bukti hubungan terbalik antara otonomi jadwal dan kinerja kreatif di antara subjek impulsif rendah (Brem \& Utikal, 2019). Oleh karena itu, Brem dan Utikal menyarankan kebijakan manajemen yang optimal bergantung pada fokus manajer pada kinerja kreatif atau rutin dan jenis karyawan yang diawasi oleh manajer. Untuk penampilan rutin, model waktu kreativitas tidak memiliki pengaruh yang signifikan.

Setiap orang punya siklus yang bersifat pribadi untuk berada dalam kondisi mental tertentu. Setiap orang berjalan dalam siklus harian dan memiliki waktu tertentu untuk menjadi kreatif atau imajinatif dalam berpikir dan sebaliknya memiliki waktu tertentu pula untuk menjadi paling mampu untuk berpikir secara analitis (Timpe, 1992). Berkaitan dengan waktu, Timpe juga berpendapat untuk membiasakan menentukan batas waktu. Hal ini menjadi sifat manusia untuk menunda-nunda masalah. Tetapi orang yang penuh gagasan yang berhasil menemukan bahwa masa paling kreatif mereka berada dalam gelombang-gelombang, mereka mendapatkan gagasan-gagasannya yang terbaik ketika mereka berusaha sekeraskerasnya (Timpe, 1992).

Dalam penelitian ini, sebagian informan terkadang membutuhkan waktu tertentu secara khusus untuk memecahkan masalah kreatifnya. 


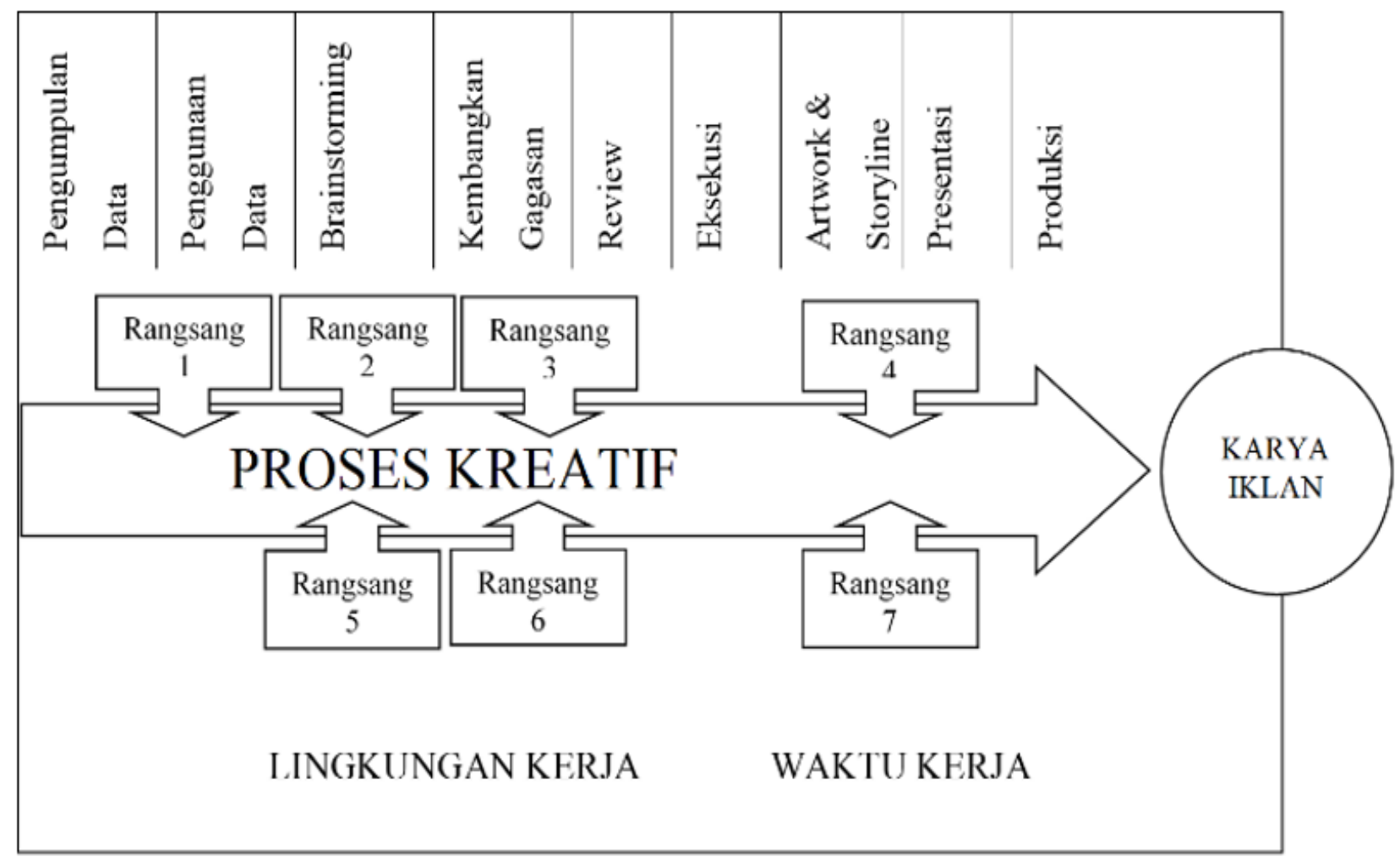

Sumber: Diolah dari hasil penelitian, 2020

Gambar 1 Model Proses Kreatif Kreator Iklan

Mereka memilih waktu tertentu karena sangat mengenali kapan mereka berada dalam saat paling mampu berpikir kreatif. Pilihan ini umumnya didasarkan pengalaman selama mereka menjalani profesinya. Namun, bagi sebagian informan lain merasa harus mampu bekerja di semua waktu karena tuntutan pekerjaan terkadang menuntutnya serupa itu.

Seluruh penjelasan mengenai proses kreatif kreator iklan berikut faktor-faktor eksternal yang turut mewarnai proses yang berlangsung digambarkan dalam gambar 1 .

\section{SIMPULAN}

Berdasarkan temuan penelitian di atas dapat disimpulkan bahwa proses kreatif para kreator dapat berlangsung pada banyak tahapan, maka perhatian manajemen dalam pengelolaan SDM pada Divisi Kreatif seyogyanya tidak hanya terpusat pada tahapan tertentu saja. Perhatian berupa keleluasaan dan kebebasan berkarya para kreator mungkin bisa lebih fleksibel. Selain itu, pengelolaan tempat kerja dan fleksibilitas waktu kerja para kreator ada baiknya mendapat perhatian mengingat keduanya dapat berkontribusi terhadap proses kreatif yang mereka lalui.

Peneliti menyadari banyak hal masih tersembunyi. Jenis rangsang untuk memicu proses kreatif, misalnya mungkin masih 
terbuka untuk kemungkinan-kemungkinan lain.

Peneliti sangat menyadari, sekalipun terdapat

12 informan yang menjadi subyek penelitian, hanya 4 orang saja yang datanya tergali cukup banyak. Besar kemungkinan kemampuan mengartikulasikan pengalaman seseorang sangat erat kaitannya dengan jabatan dan jam terbang bekerja dalam profesi yang mereka pilih. Kebetulan keempat orang yang dimaksud memiliki posisi jabatan creative director dengan penglaman kerja cukup panjang. Oleh sebab itu penelitian lebih lanjut terhadap subyek dalam jabatan tertentu dengan jam terbang tertentu sangat disarankan.

\section{DAFTAR PUSTAKA}

Brem, A., \& Utikal, V. (2019). How to manage creativity time? results from a social psychological time model lab experiment on individual creative and routine performance. Creativity and Innovation Management, 28(3), 291-305.

Creswell, J. W. (2013). Qualitative inquiry and research design: Choosing among five traditions. In Qualitative Health Research (Vol. 9, Issue 5, p. 403). https://doi. org/10.1111/1467-9299.00177

Danek, A. H., \& Salvi, C. (2018). Moment of Truth: Why Aha! Experiences are Corre. Journal of Creative Behavior, 54(2), 484486.

Fuss, M., \& Daniel, G. R. (2020). Safe spaces for enabling the creative process in classrooms. Australian Journal of Teacher Education, 45(8).

Kotler, P., \& Keller, K. L. (2016).
Marketing Management. In Global Edition (Vol. 15E, Issue 4). https://doi. org/10.1080/08911760903022556

Kristensson, P., \& Norlander, T. (2003). The creative product and process in computermediated groups. The Journal of Creative Behavior, 37(4), 223-243.

Kumar, V., \& Gupta, S. (2016). Conceptualizing the Evolution and Future of Advertising. Journal of Advertising, 45(3), 302-317. https://doi.org/10.1080/00913367.2016.11 99335

Munandar, U. (2012). Pengembangan kreativitas anak berbakat. Jakarta: Rineka Cipta.

Reiter-Palmon, R. (2017). The role of problem construction in creative production. Journal of Creative Behavior, 51(4), 323-326.

Rosso, B. D. (2014). Creativity and constraints: exploring the role of constraints in the creative processes of tesearch and development teams. Organiztion Studies, 35(4), 551-585.

Sánchez-Ruiz, M. (2020). Creativity. In The Wiley Encyclopedia of Personality and Individual Differences: Models and Theories. New Jersey: John Wiley \& Sons Ltd.

Shimp, T. A., \& Andrews, J. C. (2018). Advertising, promotion and other spects of integrated marketing communications, . Cencage.

Solomon, R. (2016). The Art of Client Service: The Classic Guide. New Jersey: John Wiley \& Sons.

Stuhlfaut, M. W. (2011). The creative code an organisational influence on the creative process in advertising. International Journal of Advertising, 30(2), 323-326. https://doi.org/10.2501/IJA-30-1-000-000

Timpe, A. D. (1992). Kreativitas. Jakarta: Elex 
Media Komputindo.

Turnbull, S., \& Wheeler, C. (2017). The advertising creative process: a study of uk agencies. Journal of Marketing Communications, 23(2), 176-194.
Wöhler, J., \& Reinhardt, R. (2021). The users' perspective on how creativity techniques help in the idea generation process - a repertory grid study. Creativity and Innovation Management, 30(1), 144-163. 